\title{
ACUTE EFFECTS OF RESTRAINT, SHOCK AND TRAINING IN THE ELEVATED T-MAZE ON NORADRENALINE AND SEROTONIN SYSTEMS OF THE PREFRONTAL CORTEX
}

\author{
Norma Laura García-Saldívar', María Reyes González-López' ${ }^{1}$ Juana Monroy², \\ Roberto Domínguez ${ }^{2}$, Sara Eugenia Cruz-Morales ${ }^{1 *}$ \\ ${ }^{1}$ Proyecto de Psicofarmacología, División de Investigación y Posgrado, Facultad de Estudios Superiores-Iztacala - UNAM., \\ ${ }^{2}$ Unidad de Biología de la Reproducción, Facultad de Estudios Superiores - Zaragoza - UNAM
}

Recibido, abril 25/2014

Concepto de evaluación, mayo 8/2014

Aceptado, mayo 15/2014
Referencia: García-Saldívar, N.L., González-López, M.R., Monroy, J., Domínguez, R., Cruz-Morales, S.E. (2014). Efectos agudos de la restricción, choque y entrenamiento en el laberinto elevado en $\mathrm{T}$ en los sistemas de noradrenalina y serotonina en la corteza prefrontal. Acta Colombiana de Psicología, 17 (2), pp. 23-31. DOI:10.14718/ACP.2014.17.2.3

\begin{abstract}
The prefrontal cortex (PFC) participates in cognitive functions and stress regulation. Noradrenaline (NA) and serotonin (5-HT) levels in some regions of the central nervous system are modified by acute stress. The effects depend on the type of stressor and the time elapsed between the presence of the stressor and the assessment. The aims of the present study were to assess the acute effect of different stressors on NA and 5-HT activities in the PFC and its relation with corticosterone levels. Independent groups of male Wistar rats (250-280 g) were submitted to restraint, footshock or training in the elevated T-maze (ETMT). The animals were sacrificed immediately (T0) or one hour (T1) after stress exposure. An untreated group sacrificed concurrently with treated animals was included as control. Samples of the PFC were dissected and the concentration of NA, 5-HT and their metabolites were measured by HPLC. Corticosterone levels were measured in serum. None of the treatments modified NA levels in the PFC. Animals exposed to footshock or ETMT showed significantly higher concentrations of 5-HT at T0. Restraint and footshock treatments were associated with higher corticosterone levels at T0 and T1 after the respective treatment. Taken together the results show that in the PFC, the noradrenergic and serotonergic systems, and the corticosterone levels respond in different ways to different stressors.

Key words: Stressors, noradrenaline, serotonin, prefrontal cortex, corticosterona.
\end{abstract}

\section{EFECTOS AGUDOS DE LA RESTRICCIÓN, CHOQUE Y ENTRENAMIENTO EN EL LABERINTO ELEVADO EN T EN LOS SISTEMAS DE NORADRENALINA Y SEROTONINA EN LA CORTEZA PREFRONTAL}

\begin{abstract}
Resumen
La corteza prefrontal (CPF) participa en las funciones cognitivas y la regulación del estrés. Las concentraciones de noradrenalina (NA) y serotonina (5-HT) en algunas regiones en el sistema nervioso central son modificadas por el estrés agudo. El efecto depende del estresor y del tiempo que transcurra entre el estresor y la evaluación. El objetivo del presente estudio fue evaluar el efecto agudo de diferentes estresores en la actividad de la NA y 5-HT en la CPF y su relación con los niveles de corticosterona. Grupos independientes de ratas (250-270 g) fueron sometidos a restricción, choque o entrenamiento en el laberinto elevado en $\mathrm{T}$ (ELET). Los animales fueron sacrificados inmediatamente (T0) o una hora (T1) después de la exposición al estrés. Un grupo no tratado, sacrificado al mismo tiempo que los animales tratados, se incluyó como control. Las muestras de la CPF fueron disecadas y la concentración de NA, 5-HT y sus metabolitos fue detectada por la técnica de HPLC. Las concentraciones de corticosterona fueron medidas en el suero. Ninguno de los tratamientos modificó las concentraciones de NA en la CPF. Al T0 los animales expuestos a choque o al ELET mostraron concentraciones de 5-HT significativamente mayores que el control. Los tratamientos de restricción y choque estuvieron asociados con altas concentraciones de corticosterona al T0 y a T1 después del tratamiento respectivo. En conjunto, los resultados mostraron que en la CPF los sistemas noradrenérgico y serotonérgico y la concentración de corticosterona responden en forma diferente a los distintos estresores.

Palabras clave: Estresores, noradrenalina, serotonina, corteza prefrontal, corticosterona.
\end{abstract}

* Psychopharmacology, FES-Iztacala, UNAM, Av. De los Barrios \# 1, Los Reyes Iztacala, Tlalnepantla, México, Zip Code 54090, México. Tel. (52-55) 5623-1333 \# 3975. Fax. (52-55) 5390-7604. saracruz@unam.mx

Supported by DGAPA, UNAM: IN300806 


\title{
EFEITOS AGUDOS DA RESTRIÇÃO, CHOQUE E TREINAMENTO NO LABIRINTO ELEVADO EM T NOS SISTEMAS DE NORADRENALINA E SEROTONINA NO CÓRTEX PRÉ-FRONTAL
}

\begin{abstract}
Resumo
O córtex pré-frontal (CPF) participa nas funções cognitivas e na regulação do estresse. As concentrações de noradrenalina (NA) e serotonina (5-HT) em algumas regiões do sistema nervoso central são modificadas pelo estresse agudo. O efeito depende do estressor e do tempo que transcorra entre o estressor e a avaliação. O objetivo do presente estudo foi avaliar o efeito agudo de diferentes estressores na atividade da NA e 5-HT no PFC e sua relação com os níveis de corticosterona. Grupos independentes de ratos (250-270 g) foram submetidos a restrição, choque ou treinamento no labirinto elevado em T (ELET). Os animais foram sacrificados imediatamente (T0) ou uma hora (T1) depois da exposição ao estresse. Um grupo não tratado, sacrificado ao mesmo tempo que os animais tratados, incluiu-se como controle. As mostras do PFC foram dissecadas e a concentração de NA, 5-HT e seus metabolitos foi detectada pela técnica de HPLC. As concentrações de corticosterona foram medidas no soro. Nenhum dos tratamentos modificou as concentrações de NA no PFC. Em T0 os animais expostos a choque o ao ELET mostraram concentrações de 5-HT significativamente maiores que o controle. Os tratamentos de restrição e choque estiveram associados com altas concentrações de corticosterona em T0 e em T1 depois do tratamento respectivo. Em conjunto, os resultados mostraram que no PFC os sistemas noradrenérgico e serotonérgico e a concentração de corticosterona respondem de maneira diferente aos diferentes estressores.

Palavras chave: Estressores, noradrenalina, serotonina, córtex pré-frontal, corticosterona.
\end{abstract}

\section{INTRODUCTION}

According to Pacák and Palkovits (2001), a stressor is a stimulus that disrupts homeostasis, and is classified based upon their character, duration and intensity. Psychological stressors affect emotional processes and may result in behavioral changes such as anxiety, fear or frustration (Cruz Becerra, 2003; Pacak \& McCarty, 2000). Different kinds of stressors elicit differential responses in the mechanisms regulating the feedback of the hypothalamic-pituitary-adrenal (HPA) axis, as well as in the neurochemistry of different regions of the central nervous system (CNS) (Adell, Casanovas \& Artigas, 1997; Fujino, et al., 2002; Pacák, Palkovits, Kvetnanský, Yadid, Kopin \& Goldstein, 1995; Pacák, Palkovits, Yadid, Kvetnanský, Kopin \& Goldstein, 1998).

Behavioral procedures involving footshock exposure or other aversive stimuli are experimental tools used to study learning and memory (Bammer, 1982; Myhrer, 2003), and stress responses (Sandi \& Pinelo-Nava, 2007). Footshock stress activates the HPA axis and immobilization is a potent stressor eliciting psychological and physical responses such as an increase in noradrenaline (NA), adrenaline (A), as well as corticosterone serum levels (Pacák \& McCarty, 2000).

The elevated T-maze (ETM) is a model used to assess memory and anxiety (Graeff, Viana \& Tomaz, 1993; Viana, Tomaz \& Graeff, 1994); however, data on its effects as stressor are scarce (Blanco, Castilla-Ortega, Miranda, Begega, Aguirre, Arias et al., 2009; Cruz-Morales, GarcíaSaldívar, González-López, Castillo-Roberto, Monroy \& Domínguez, 2008). Female rats exposed to the elevated plus-maze show an acute and chronic decrease in serotonergic activity in the dorsal raphe nucleus (DRN). In male rats, the same procedure resulted in a decrease in serotonergic activity in the median raphe nucleus (MRN) (Domínguez, Cruz-Morales, Carvalho, Xavier \& Brandão, 2003b).

The prefrontal cortex (PFC) is a limbic forebrain region involved in learning, memory, attention, and stress responses (Holmes \& Wellman, 2009; Mokler, Torres, Galler \& Morgane, 2007; Shin \& Liberzon, 2010). The medial prefrontal cortex (mPFC) seems to inhibit the HPA responses to emotional stress through influencing the paraventricular hypothalamic nucleus $(\mathrm{PVH})$; this modulatory role of $\mathrm{mPFC}$ is mediated by noradrenergic pathways originating in the locus coeruleus (LC) (Radley, Williams $\&$ Sawchenko, 2008).

Noradrenergic pathways originating in the LC (Radley et al., 2008) and serotonergic signals arising from the DRN and MRN (Robbins \& Roberts, 2007) participate in the regulation of PFC functions.

In Wistar male rats exposed to acute forced-swimming stress for 15 minutes and sacrificed immediately after treatment, the 5-hydroxyindoleacetic acid (5-HIAA) and corticosterone levels increased, with no changes in 5-HT turnover and NA levels in the PFC (De la Garza \& Mahoney, 2004). Adult male rats exposed to immobilization stress during two hours had corticosterone concentrations approximately 4-fold higher than baseline levels (Lucas, Wang, McCall $\&$ McEwen, 2007). In mice submitted to rat-exposure test, a prey-predator (mouse-rat)-based model, corticosterone levels increased during the first 15 minutes after stress, and 
turned normal after 30 minutes (Amaral, Santos-Gomes \& Nunes-de-Souza, 2010). Natelson, Tapp, Adamus, Mittler and Leven (1981) studied the effects of submitting groups of rats to 30 seconds of constant current grid footshock ( 0 , $0.25,0.5,1,2,4 \mathrm{~mA})$. Rats receiving any level of electric shock showed similar increases in corticosterone plasma levels, while NA and adrenaline plasma levels increased in a stepwise fashion with the stress magnitude.

Most studies on stress report changes in plasma corticosterone levels and NA, dopamine (DA) and 5-HT levels in various cerebral areas after chronic stress; but very few have examined the effect of acute stress exposure to a single stressor. When acute stress effects with exposure to footshock are reported, usually the procedures imply the administration of several shock treatments of 20 minutes sessions or more (Shinba, Ozawa, Yoshii \& Yamamoto, 2010; Swiergiel, Leskov \& Dunn, 2008).

The aims of the present study were to compare the acute effects of three stressors (restraint, footshock and training in the elevated T-maze) on the noradrenergic and serotonergic systems of the PFC, and in corticosterone serum levels.

\section{METHOD}

\section{Subjects}

The experiments were performed following the guidelines established by the Society for Neuroscience (SfN). Groups of adult naïve Wistar male rats (250-270 g) from the FES-Iztacala-UNAM vivarium were used. Animals were housed in groups of four in acrylic cages with food and water ad libitum, and a 12-hr light: 12-hr dark cycle (lights on at 08:00 hr). All tests were performed between 14:00 and 17:00 hr. The room where the experimental tests were carried out was $10 \mathrm{~m}$ away from the animal house.

\section{Apparatus}

Restrainers. Acrylic cylindrical restrainers (PLAS LAB. INC) with holes to allow adjustment to the size of the experimental subjects were used.

Footshock. Shuttle Box (Gemini, San Diego Instruments, USA).

ETM. The ETM consisted of one enclosed arm and two open arms $(50 \mathrm{~cm} \times 10 \mathrm{~cm})$ elevated $50 \mathrm{~cm}$ above the ground; the wall of the close arm was $40 \mathrm{~cm}$ high. The ETM was in an isolated room with low light (50 lux).

HPLC apparatus. The HPLC apparatus consisted of an isocratic pump (PerkinElmer Co., Norwalk,CT, USA, model LC-250), a Rheodyne injection valve and a C18 column (Bionalytical Systems, Inc., USA), protected by a precolumn cartridge filter (Bionalytical Systems, Inc., USA).

\section{Procedure}

To diminish the stress caused by experimental manipulations, the rats in this study were handled for 10 minutes during eight days prior the experiments. Animals were randomly assigned to eight different independent groups: three treatment groups and two control groups (not exposed to any stressor), sacrificed at $17.00 \mathrm{hr}$.

Restraint: Two groups of rats were submitted to restraint $(\mathrm{n}=6)$ as previously described (Cruz-Morales et al., 2008); shortly, after handling period, subjects were immobilized for 15 minutes in a restrainer.

Footshock: Two groups of animals were submitted to footshock $(\mathrm{n}=8)$ as previously (Cruz-Morales, DuránArévalo, Díaz del Guante, Quirarte \& Prado-Alcalá, 1992). Briefly, the rats received a 5 seconds footshock $(2.5 \mathrm{~mA})$ in the shuttle box.

ETM: Another two groups of animals $(\mathrm{n}=8)$ were trained in the ETM(ETMT) following the methodology previously described (Cruz-Morales, et al., 2008). Three avoidance trials took place and in each of them the subject was placed in the enclosed arm. When the rat entered the open arm, it was removed, and another trial started. The inter trial interval was of 30 seconds. After avoidance trials, each subject was placed in the open arm until it escaped from it.

NA and 5-HT measurements. Immediately (T0) or 1 hour (T1) after the behavioral procedures, the subjects of each experimental procedure and control group were sacrificed by decapitation. The brain was removed and kept in liquid nitrogen. PFC samples were collected, following parameters of the stereotaxic atlas (Paxinos \& Watson, 1997). NA, methoxyhydroxyphenilglycol (MHPG), 5-HT and 5-HIAA concentrations were measured following the previously described methodology (Domínguez, CruzMorales, Carvalho, Xavier \& Brandão, 2003a; Domínguez, et al., 2003b). In brief, the tissue samples were weighed, homogenized in $300 \mu$ of $0.1 \mathrm{~N}$ perchloric acid, centrifuged at $12,500 \mathrm{rpm}$ for 30 minutes at $-4{ }^{\circ} \mathrm{C}$ the supernatant was filtered and $20 \mu \mathrm{l}$ of this extract was injected into the HPLC system for analysis.

The concentration of NA, MHPG, 5-HT and 5-HIAA was quantified electrochemically using a BAS LC-4C amperometric detector and an LC-4A glassy carbon transducer cell (Bionalytical Systems, Inc.). The mobile phase consisted of $0.1 \mathrm{M}$ citrate buffer (pH 3.0) with $100 \mathrm{mg}$ of 1-octane-sulfonic acid (Sigma, St. Louis, MO, USA), 20 $\mathrm{ml}$ of acetonitrile and $15 \mathrm{ml}$ of tetrahydrofuran (Omnisolve and Science, Canada). The mobile phase was pumped at a flow rate of $1.2 \mathrm{ml} / \mathrm{min}$. Results are expressed as nanograms of analyte per milligram of wet tissue ( $\mathrm{ng} / \mathrm{mg}$ ). MHPG/ NA and 5-HIAA/5-HT ratios were used to calculate the activity (turnover) of the noradrenergic and serotonergic 
systems (Kerdelhue, et al., 1989), as previously described (Domínguez, et al., 2003a; 2003b).

Corticosterone measurement: Blood trunk samples (3 $\mathrm{ml}$ ) were obtained and centrifuged at $3000 \mathrm{rpm}$ and the serum stored at $-20^{\circ} \mathrm{C}$ until concentrations of corticosterone were measured using enzyme-linked immune sorbent assay (ELISA) using kits provided by Assays Design, Ann Arbor, Michigan, USA. Analytical results are expressed in ng/ $\mathrm{ml}$. The lower limit of detection was $0.027 \mathrm{ng} / \mathrm{ml}$ and the intra- and inter-assay percent variation coefficients were 5.3 and 9.87 respectively.

\section{RESULTS}

Results on NA, MHPG, 5-HT, 5-HIAA levels, noradrenergic and serotonergic activity, and corticosterone levels were analyzed using a two-way analysis of variance (ANOVA) test followed by the Least Significant Difference (LSD) post hoc test; a $\mathrm{p}$ value $\leq 5 \%$ was considered significant.

Corticosterone: Significant differences were detected for treatment factor $\left[\left(\mathrm{F}_{3,32}\right)=4.82, \mathrm{p}=0.006\right]$, for the interaction (treatment $\mathrm{x}$ time) $\left[\left(\mathrm{F}_{3,32}\right)=5.49, \mathrm{p}=0.003\right]$, while the time factor yielded no significant differences $\left[\left(\mathrm{F}_{1,32}\right)=0.19, \mathrm{p}=0.6\right]$.

Compared to the control group, corticosterone levels in the group of restrained animals sacrificed at $\mathrm{T} 0$ were higher $(p=0.014)$ and similar when the animals were sacrificed at T1. In footshock treated rats corticosterone levels were similar to control levels at $\mathrm{T} 0$ and higher in rats sacrificed at T1 $(p=0.0015]$. The ETM training group did not modified corticosterone levels (Figure 1).

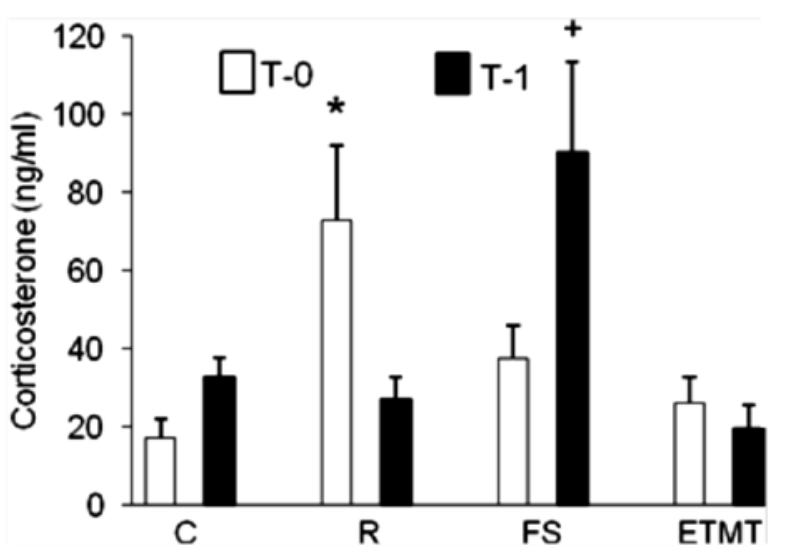

Figure 1. Mean $( \pm \mathrm{SEM})$ of corticosterone plasma levels in rats exposed to different stressors: restraint for 15 minutes (R), footshock (FS) or elevated T-maze training (ETMT). ${ }^{*} \mathrm{p}<0.05$ vs. $\mathrm{C} 0,{ }^{+} \mathrm{p}<0.05$ vs. C1.
Noradrenergic system: For the concentration of the metabolite MHPG significant differences were detected for treatment $\left[\left(\mathrm{F}_{3,46}\right)=11.05, \mathrm{p}=0.0001\right]$ and time factors $\left[\left(\mathrm{F}_{1,46}\right)=7.95, \mathrm{p}=0.007\right]$. No differences were detected for the interaction $\left[\left(\mathrm{F}_{3,46}\right)=1.60, \mathrm{p}=0.20\right]$.

Independently of the stress treatment, the concentrations of MHPG at T0 and T1 were lower than their respective control group (p's $<0.05$ ) (Figure 2).

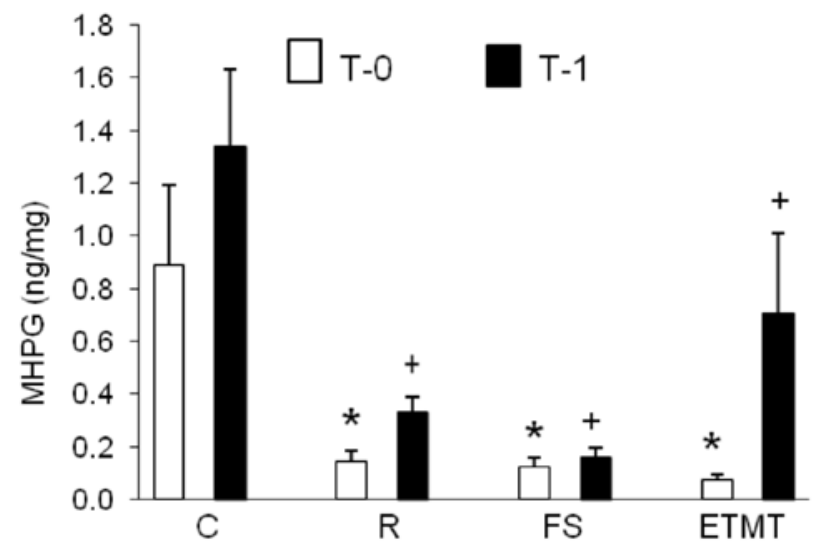

Figure 2. Mean $( \pm$ SEM) of MHPG levels in rats exposed to different stressors: restraint for 15 minutes (R), footshock (FS) or elevated T-maze training (ETMT). ${ }^{*} \mathrm{p}<0.05$ vs. $\mathrm{C} 0 ;{ }^{+} \mathrm{p}<0.05$ vs. $\mathrm{C} 1$.

No significant differences in NA concentration were observed between animals from the stress treatment and control group (Figure 3).

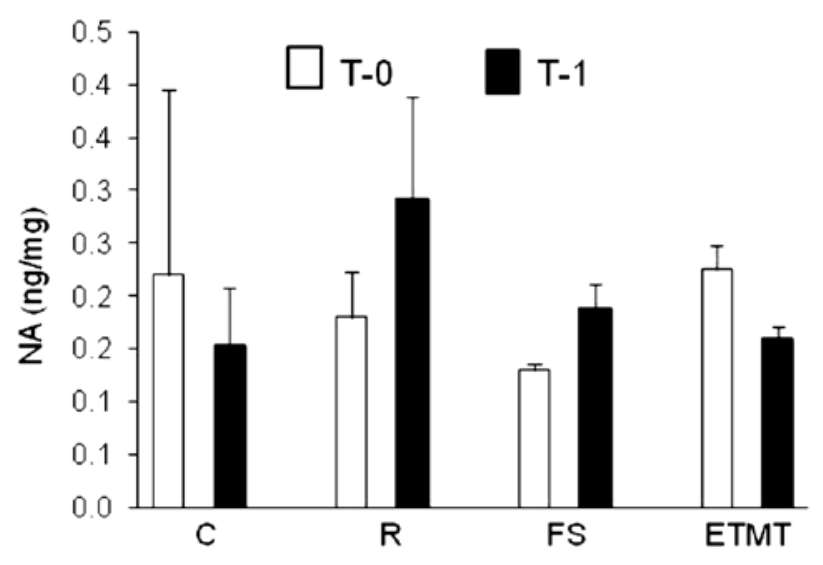

Figure 3. Mean $( \pm$ SEM) of NA levels in rats exposed to different stressors: restraint for 15 minutes (R), footshock (FS) or elevated T-maze training (ETMT).

For the NA activity significant differences were found for time factor $\left[\left(\mathrm{F}_{1,46}\right)=10.94, \mathrm{p}=0.001\right]$. A reduction in 
noradrenergic activity (Figure 4) was observed in footshock group at $\mathrm{T} 1$ compared with the $\mathrm{C}$ group.

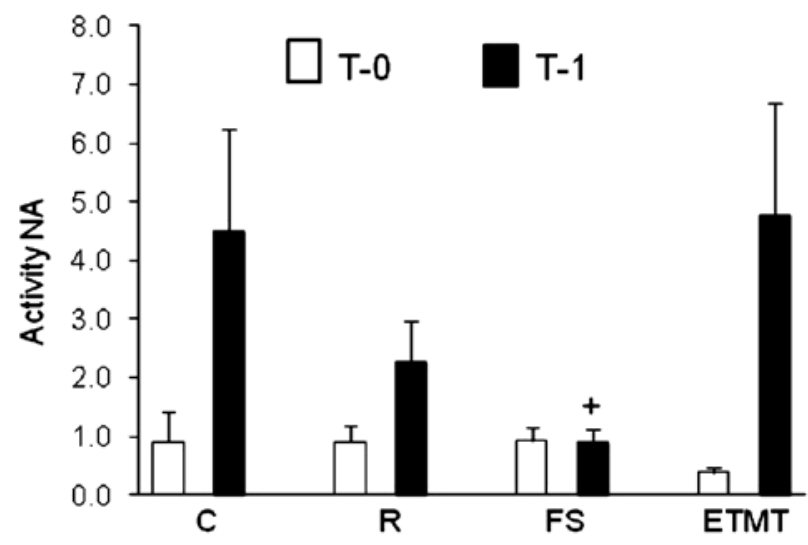

Figure 4. Mean $( \pm$ SEM) of NA activity in rats exposed to different stressors: restraint for 15 minutes (R), footshock (FS) or elevated T-maze training (ETMT). ${ }^{+} \mathrm{p}<0.05$ vs. $\mathrm{C} 1$.

Serotonergic system: For the metabolite 5-HIAA(Figure 5) significant differences were found for treatment $\left[\left(\mathrm{F}_{3.46}\right)=6.61\right.$, $\mathrm{p}=0.0008]$ and for the interaction (treatment $\mathrm{x}$ time) $\left[\left(\mathrm{F}_{3,46}\right)=\right.$ $3.41, \mathrm{p}=0.024]$. Compared to the control group, all stress treatment studied resulted in lower 5-HIAA concentrations at $\mathrm{T} 0(\mathrm{p}<0.05)$. At $\mathrm{T} 1$ the concentrations were similar to their respective control group.

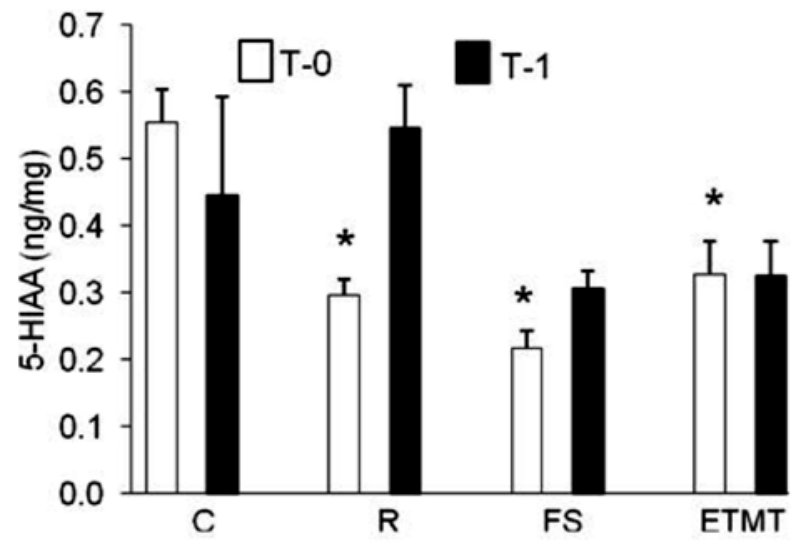

Figure 5 . Mean $( \pm \mathrm{SEM})$ of 5-HIAA levels in rats exposed to different stressors: restraint for 15 minutes (R), footshock (FS) or elevated T-maze training (ETMT). ${ }^{*} \mathrm{p}<0.05$ vs. C.

Two-way ANOVA revealed significant differences for treatment factor $\left[\left(\mathrm{F}_{3,46}\right)=2.91, \mathrm{p}=0.044\right]$, and the interaction (treatment $\mathrm{x}$ time) $\left[\left(\mathrm{F}_{3,46}\right)=4.02, \mathrm{p}=0.012\right]$ in $5-\mathrm{HT}$ concentrations.
At T0, 5-HT levels were higher than control in rats submitted to footshock or training in the ETM (p's $<0.05)$. No significant differences were observed at T1 (Figure 6).

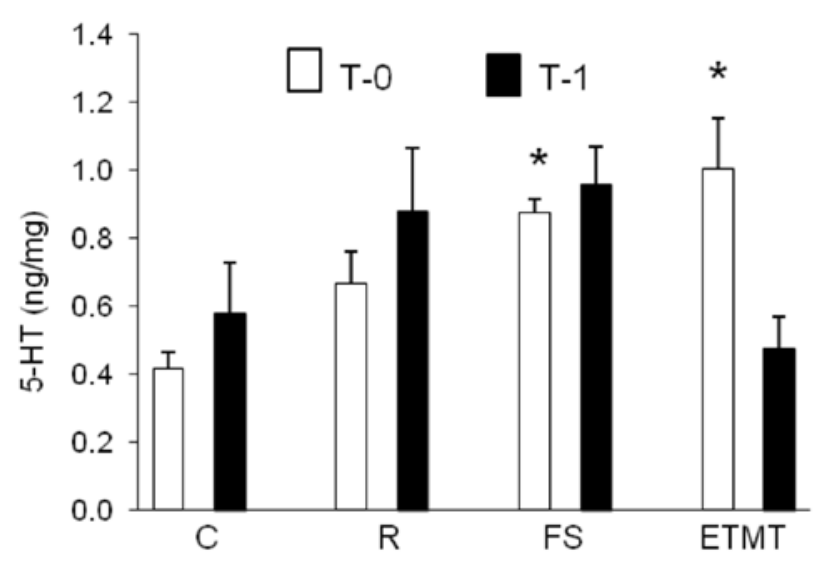

Figure 6. Mean ( \pm SEM) of 5-HT levels in rats exposed to different stressors: restraint for 15 minutes (R), footshock (FS) or elevated T-maze training (ETMT). ${ }^{*} \mathrm{p}<0.05$, vs. C.

For the activity of 5-HT significant differences were observed for treatment $\left[\left(\mathrm{F}_{3,46}\right)=10.13, \mathrm{p}=0.0001\right]$ and for the interaction (treatment $\mathrm{x}$ time) $\left[\left(\mathrm{F}_{3,46}\right)=6.69, \mathrm{p}=0.0007\right]$.

Compared to control levels, serotonergic activities at $\mathrm{T} 0$ (Figure 7) were lower in all experimental groups ( $p$ 's $<0.05$ ). At T1 no significant differences were detected.

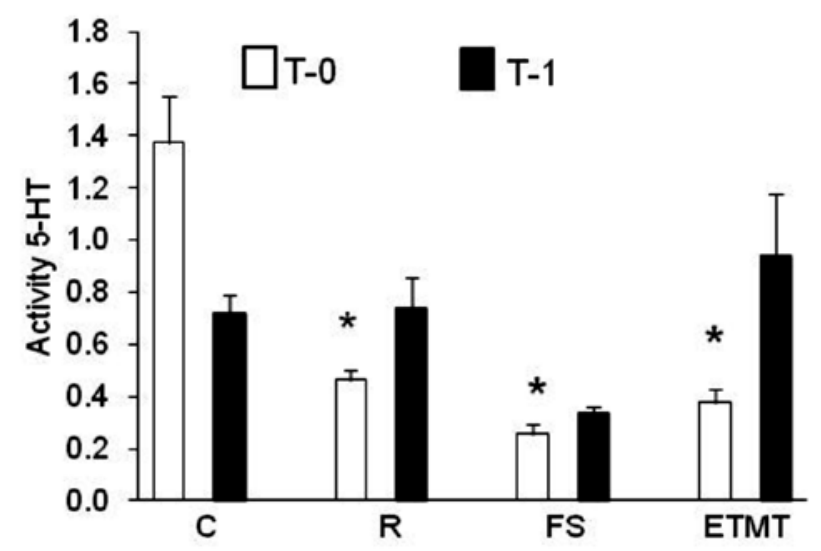

Figure 7. Mean $( \pm \mathrm{SEM})$ of 5-HT activity in rats exposed to different stressors: restraint for 15 minutes (R), footshock (FS) or elevated T-maze training (ETMT). ${ }^{*} \mathrm{p}<0.05$ vs. $\mathrm{C}$.

\section{DISCUSSION}

The effects of stress vary depending on different variables such as the type of stressor, the time elapsed between stress 
treatment and assessment, the structure evaluated, and the acuteness or chronic nature of the stressor. These results are in accordance with those from others studies showing that the acute effect of diverse stressors has different effects on several neurochemical and endocrine parameters. There is evidence that a wide range of physiological and behavioral responses depend on the particular characteristics of the stressor (Adell, et al., 1997; Fujino et al., 2002; Pacák, et al., 1995, 1998).

Corticosterone secretion presents a circadian rhythm. Consequently, the effects of stressors will vary according to the time of their administration and the time of measurement of plasma corticosterone concentrations (Atkinson \& Waddell, 1997).

According to Szafarczyk et al. (1993) the increases of ACTH and plasma corticosterone levels following ether stress takes few minutes. The present results show that the response to stress of the HPA system varies according to the type of stress treatment. For instance, corticosterone levels increased significantly immediately (T0) after restraint treatment, and returned to base levels at T1. In turn, corticosterone levels in animals treated with footshock stress were not altered at T0, but were significantly higher at T1. Such differences can be explained by the way that corticosterone is synthesized. Steroid hormones are released immediately after synthesis (Domínguez \& Cruz-Morales, 2011). The increase in corticosterone levels reflects the synthesis of the new hormone. In restrained rats, the time elapsed between the effects of the stressor and the corticosterone measurement was 15 minutes, while for the footshock was five seconds. Since the corticosteroids synthesis takes several minutes (Domínguez \& Cruz-Morales, 2011), the stimulation of the HPA axis by shock was not enough to increase corticosterone levels five seconds after stress.

This is consistent with the results of previous studies demonstrating that corticosterone release depends on the type of stressor administered (Armario, Montero \& Balasch, 1986).

The apparent lack of effects on corticosterone level of training in the ETMT treatment (a low stress stimulus) can be explained by the relatively low severity of the stressor, while restraint and electric shock are considered strong stressful stimuli (Kant, Mougey, Pennington \& Meyerhoff, 1983; Rabasa, Muñoz-Abellán, Daviu, Nadal \& Armario, 2011).

According to Kvetnansky, Sabban and Palkovits (2009), acute stress leads to transient alterations in brain's catecholaminergic system and is followed by transient activation of the HPA axis. Depending on the kind and intensity of the stressful treatment, homeostasis can be restored and the activity of the catecholaminergic neurons returns to "unstressed" levels.

Different types of stress modify the noradrenergic and serotonergic system of the PFC in different ways. Tail pinch, forced swimming or predator exposure increased extracellular 5-HT levels in amygdala and PFC (Chaouloff, 2000), whereas exposure to shock and psychological stress decreased the levels of NA in cerebral cortex, amygdala and hypothalamus (Iimori, et al., 1982).

The MHPG results from the enzymatic activity of monoamine oxidase present in the presynaptic ending on the recaptured NA (Kuhar, Minneman \& Muly, 2006). The reduction in MHPG levels at T0 after restraint, footshock or ETMT suggests that the effects of an acute stressor reduced the NA recapture system's efficiency. The present results suggest that the mechanism by which each stressor reduces NA recapture is different. For restraint, the increase in $\mathrm{CRH}, \mathrm{ACTH}$ and corticosterone serum levels could be some of the factors.

Another possibility to explain the lower levels of MHPG in rats submitted to footshock or ETMT treatment is the increase in $\mathrm{CRH}$ levels, which precede the ACTH release. There is evidence that the cerebral NA levels increases following intracerebral CRH administration, but the acute effects (seconds) of CRH into the noradrenergic neurons are inhibitory, and excitation occurs only much later (Dunn \& Swiergiel, 2008). Then, the lower MHPG levels would be the result of the acute inhibitory effects of the elevation in $\mathrm{CRH}$ release induced by the stressors. In the present study, the rats treated with footshock stress or ETMT assessed at $\mathrm{T} 0$ were sacrificed five to 120 seconds after treatment. Accordingly, the low MHPG levels observed may reflect the inhibitory effects of $\mathrm{CRH}$.

There is evidence that the chronic oral administration of corticosterone significantly increased mRNA levels of NA transporter in the frontal cortex (Fan, et al., 2014). The effect on NA and 5-HT uptake resulting from the acute and chronic administration of some drugs depends on the time of administration (Mannari et al., 2008).

According to Hendley et al. (1977), the kinetic constants for NA uptake in cerebral cortex did not induce the same response with different stressors (restraint, cold exposure, forced swimming, or shock). Furthermore, the kinetic constants for NA varied with the duration of the shock, increased after 5 minutes shock (1 second duration, 1.6 $\mathrm{mA}$ ) and no changes were detected for the 10 or $30 \mathrm{~min}-$ utes shock. According to Shinba et al. (2010), the effects of intermittent intense shock stress for $1 \mathrm{hr}$ on NA content appear to be complex; acute stress reduces the NA concentration, while chronic stress tends to increase it. Changes 
in NA are detected immediately after chronic footshock; however, these changes are delayed with acute footshock.

In the training for ETMT treatment, from its first exposure to the open arms, the animal "learns" the danger of getting out of enclosed spaces, so in the second trial open arms can be seen as a predictable stress.

A predictable shock caused no changes in NA concentrations, probably because in these conditions the use of the NA does not exceed the rate of synthesis that naturally occur (Adell, Trullas \& Gelpi, 1988).

The moderate decrease on noradrenergic turnover at $\mathrm{T} 1$ observed in animals with footshock is explained by the reduction in MHPG concentrations. This lower noradrenergic turnover suggests a reduction in the activity of the NA transporter through alpha receptors in the presynaptic terminal.

The present results suggest that acute stress treatments in this study had not effects on NA levels in prefrontal cortex. Similar results were obtained in mice subjected to the smell of cat or immobilization (Smith, Davis, Gehlert \& Nomikos, 2006).

Most of the studies of chronic stress on NA in different cerebral regions report an increase in NA levels (Finlay, Zigmond \& Abercrombie, 1995). However, some opposite effects have also been reported (Shanks, Griffithst \& Anisman, 1994). Such differences could be related to the kind of stressor and the time elapsed between the stressor and the brain region being analyzed.

In the present study, similarly to MHPG levels, all stress treatments resulted in 5-HIAA lower concentrations than control levels at T0. At T1, no significant differences were observed. The difference in the capacity of these metabolites to return to their initial levels can be explained by the different stress sensitivity of the neurons providing noradrenergic and serotonergic innervations to the CPF.

According to Kirby, Chou-Green, Davis and Lucki (1997) different types of stressors produce different effects in serotonergic system. Rats exposed to two different intensities of shock stress for 30 minutes did not modify the 5-HT metabolism in the medial prefrontal cortex (mPFC), but a high-intensity shock increased the 5-HT metabolism in the $\mathrm{mPFC}$, nucleus accumbens, and lateral hypothalamus (Inoue, Tsuchiya \& Koyama, 1994).

The present results show that the noradrenergic and serotonergic systems in the PFC do not respond in a parallel way to the same stressor. In contrast to NA levels, 5-HT levels were higher in rats submitted to footshock and ETMT (T0), suggesting that there are different mechanisms involved in NA and 5-HT recapture, depending on the stressor. The results obtained in rats with restraint treatment suggest an increase in synthesis and transport of 5-HT from the raphe nucleus to the PFC.

Furthermore, our findings suggest that in rats treated with footshock or ETMT, 5-HT release was delayed and it was accumulated in the presynaptic ending. Another possibility is that the low metabolite concentrations acted as a signal to activate the enzyme tryptophan hydroxylase which can compensate for loss of 5-HT with an increase in synthesis (Sudha \& Pradhan, 1995).

In footshock treated animals the synthesis and transport of 5-HT from the raphe nucleus to the PFC was also higher than control at $\mathrm{T} 1$, a result that was not observed in rats treated with ETMT stress. Such differences could be related to the severity of the stressor.

One explanation for different responses evoked by diverse stressors is the nature of them. Restraint and shock are considered traumatic for rodents, since they resulted in significant changes in activation of the HPA axis system immediately after treatment (T0) and one hour after (T1). In turn, these effects were not observed in rats treated with the ETM training (psychological stress). These results support the hypothesis that footshock and restraint treatment represent a threat from which the rat cannot escape, resulting in the activation of the HPA axis, and agree with the concept that each stressor has its own central neurochemical and peripheral neuroendocrine "signature" (Pácak, et al., 1998).

\section{REFERENCES}

Adell, A., Casanovas, J. M. \& Artigas, F. (1997). Comparative study in the rat of the actions of different types of stress on the release of 5-HT in raphe nuclei and forebrain areas. Neuropharmacology, 36 (4-5), 735-741.

Adell, A., Trullas, R. \& Gelpi, E. (1988). Time course of changes in serotonin and noradrenaline in rat brain after predictable or unpredictable shock. Brain Research, 459, 54-59.

Amaral, V. C., Santos-Gomes, K. \& Nunes-de-Souza, R. L. (2010). Increased corticosterone levels in mice subjected to the rat exposure test. Hormones \& Behavior, 57 (2), 128-133.

Armario, A., Montero, J. L. \& Balasch, J. (1986). Sensitivity of corticosterone and some metabolic variables to graded levels of low intensity stresses in adult male rats. Physiology \& Behavior, 37 (4), 559-561.

Atkinson, H. C, Waddell, B. J. (1997). Circadian variation in basal plasma corticosterone and adrenocorticotropin in the rat: sexual dimorphism and changes across the estrous cycle. Endocrinology, 138 (9), 3842-3848.

Bammer, G. (1982). Pharmacological investigations of neurotransmitter involvement in passive avoidance responding: A review and some new results. Neuroscience \& Biobehavioral Reviews, 6 (3), 247-296. 
Blanco, E., Castilla-Ortega, E., Miranda, R., Begega, A., Aguirre, J. A., Arias, J.L. \& Santín, L. J. (2009). Effects of medial prefrontal cortex lesions on anxiety-like behaviour in restrained and non-restrained rats. Behavioral Brain Research, 201 (2), 338-342.

Chaouloff, F. (2000). Serotonin, stress and corticoids. Journal of Psychopharmacology, 14, 139-151.

Cruz Becerra, D. (2003). Efecto de la privación social en la agresión y la ansiedad de ratas machos Wistar. Acta Colombiana de Psicología, 9, 39-49.

Cruz-Morales, S. E., García-Saldívar, N. L., González-López, M. R., Castillo-Roberto, G., Monroy, J. \& Domínguez, R. (2008). Acute restriction impairs memory in the elevated T-maze (ETM) and modifies serotonergic activity in the dorsolateral striatum. Behavioral Brain Research, 19 (1), 187-191.

Cruz-Morales, S. E., Durán-Arévalo, M. Díaz del Guante, M. A., Quirarte, G. L. \& Prado-Alcalá, R. A. (1992). A threshold for the protective effect of over-reinforced passive avoidance against scopolaminutesutese-induced amnesia. Behavioral and Neural Biology, 57 (3), 256-259.

De la Garza, R. \& Mahoney, J. J. (2004). A distinct neurochemical profile in WKY rats at baseline and response, o acute stress: implications for animal models of anxiety and depression. Brain Research, 1021 (2), 209-218.

Domínguez, R. \& Cruz-Morales, S. E. (2011). The ovarian innervation participates in the regulation of ovarian functions. Endocrinology \& Metabolic Syndrome. Retrieved April 28, 2014 from http://dx.doi.org/10.4172/2161-1017.S4-001

Domínguez, R., Cruz-Morales, S. E., Carvalho, M. C., Xavier, M. \& Brandão, M. L. (2003a). Effect of steroid injection to newborn rats on serotonin activity in frontal cortex and raphe. Neuroreport, 14 (4), 597-599.

Domínguez, R., Cruz-Morales, S. E., Carvalho, M. C., Xavier, M. \& Brandão M. L. (2003b). Sex differences in serotonergic activity in dorsal and median raphe nucleus. Physiology \& Behavior, 80 (2-3), 203-210.

Dunn, A. J. \& Swiergiel, A. H. (2008). The role of corticotropinreleasing factor and noradrenaline in stress-related responses, and the inter-relationships between the two systems. European Journal of Pharmacology, 583 (2-3), 186-193.

Fan Y, Chen P, Li Y, Cui K, Noel DM, Cumminutesutess ED, Peterson DJ, Brown RW, Zhu MY. (2014). Corticosterone adminutesutesistration up-regulated expression of norepinephrine transporter and dopaminutesutese $\beta$-hydroxylase in rat locus coeruleus and its terminutesutesal regions. Journal of Neurochemistry, 128 (3), 445-458.

Finlay, J. M., Zigmond, M. J. \& Abercrombie, E. D. (1995). Increased dopaminutesutese and norepinephrine release in medial prefrontal cortex induced by acute and chronic stress: effects of diazepam. Neuroscience, 64 (3), 619-628.

Fujino K, Yoshitake T, Inoue O, Ibii N, Kehr J, Ishida J, Nohta H. \& Yamaguchi M. (2002). Increased serotonin release in mice frontal cortex and hippocampus induced by acute physiological stressors. Neuroscience Letters, 320, 91-95.

Graeff, F. G., Viana, M. B. \& Tomaz, C. (1993). The elevated T-maze, a new experimental model of anxiety and memory: effect of diazepam. Brazilian Journal of Medical and Biological Research, 26 (1), 67-70.

Hendley, E. D., Burrows, G. H., Robinson, E. S., Heidenreich, K. A. \& Bulman, C. A. (1977). Acute stress and the brain norepinephrine uptake mechanism in the rat. Pharmacology Biochemistry and Behavior, 6 (2), 197-202.

Holmes, A. \& Wellman, C. L. (2009). Stress induced prefrontal reorganization and executive dysfunction in rodents, $\mathrm{Neu}$ roscience and Biobehavioral Reviews, 33 (6), 773-783.

Iimori, K., Tanaka, M., Kohno, Y., Ida, Y., Nakagawa, R., Hoaki, Y., et. al, (1982). Psychological stress enhances noradrenaline turnover in specific brain regions in rats. Pharmacology Biochemistry and Behavior, 16 (4), 637-640.

Inoue, T., Tsuchiya, K. \& Koyama, T. (1994). Regional changes in dopaminutesutese and serotonin activation with various intensity of physical and psychological stress in the rat brain. Pharmacology, Biochemistry and Behavior, 49 (4), 911-920.

Kant, G. J., Mougey, E. H., Pennington, L. L. \& Meyerhoff, J. L. (1983). Graded shock stress elevates pituitary cyclic AMP and plasma beta-endorphin, beta-LPH corticosterone and prolactin. Life Sciences, 33 (26), 2657-2663.

Kerdelhué, B., Bojda, F., Lesieur, P., Pasqualini, C., el Abed, A., Lenoir, V., et al, (1989). Median eminutesutesence dopaminutesutese and serotonin neuronal activity. Temporal relationship to preovulatory prolactin and luteinizing hormone surges. Neuroendocrinology, 49 (2), 176-180.

Kirby, L. G., Chou-Green, J. M., Davis, K. \& Lucki, I. (1997). The effects of different stressors on extracellular 5-hydroxytryptaminutesutese and 5-hydroxyindolacetic acid. Brain Research, 760 (1-2), 218-220.

Kuhar, M.J., Minutesutesneman, K. \& Muly, E.C. Catecholaminutesuteses. (2006). In G. J. Siegel, R. W. Albers, S.T., Brady and D.L. Price (Eds.). Basic Neurochemistry: Molecular, Cellular, and Medical Aspects 7th Edition, (pp. 211225). Burlington, MA, Elsevier Academic Press.

Kvetnansky, R., Sabban, E. L. \& Palkovits, M. (2009). Catecholaminutesutesergic systems in stress: structural and molecular genetic approaches. Physiological Reviews, 89 (2), 535-606.

Lucas, L. R., Wang, Ch., McCall, T. \& McEwen, B. S. (2007). Effects of immobilization stress on neurochemical marks in the motivational system of the male rat. Brain Research, $1155,108-115$.

Mannari, C., Origlia, N., Scatena, A., Del Debbio, A., Catena, M., Dell'agnello, G., Barraco, A., Giovannini, L., Dell'osso, L., Domenici, L., Piccinni, A. (2008). BDNF level in the rat prefrontal cortex increases following chronic but not acute treatment with duloxetine, a dual acting inhibitor of noradrenaline and serotonin re-uptake. Cellular and Molecular Neurobiology, 28 (3), 457-468. 
Mokler, D. J., Torres, O. I., Galler, J. R. \& Morgane, P. J. (2007). Stress-induced changes in extracellular dopaminutesutese and serotonin in the medial prefrontal cortex and dorsal hippocampus of prenatally malnourished rats. Brain Research, 1148, 226-233.

Myhrer, T. (2003). Neurotransmitter systems involved in learning and memory in the rat: a meta-analysis based on studies of four behavioral tasks. Brain Research Reviews, 41 (2-3), 268-287.

Natelson, B. H., Tapp, W. N., Adamus, J. E., Mittler, J. C. \& Levin, B. E. (1981). Humoral indices of stress in rats. Physiology \& Behavior, 26 (6), 1049-1054.

Pacak, K. \& McCarty, R. (2000). Acute stress response: experimental. In G Fink (Ed.) Encyclopedia of stress (pp 8-17), San Diego: Academic Press.

Pacák, K., Palkovits, M., Kvetnanský, R., Yadid, G., Kopin, I. J. \& Goldstein, D. S. (1995). Effects of various stressors on in vivo norepinephrine release in the hypothalamic paraventricular nucleus and on the pituitary-adrenocortical axis. Annual New York Academic Science, 771, 115-130.

Pacák, K., Palkovits, M., Yadid, G., Kvetnansky, R., Kopin, I. J. \& Goldstein, D. S. (1998). Heterogeneous neurochemical responses to different stressors: a test of Selye's doctrine of nonspecificity. American Journal Physiology, 275 (4 Pt2), R1247-R1255.

Pacák, K. \& Palkovits, M. (2001). Stressor specificity of central neuroendocrine responses: Implications for stress-related disorders. Endocrine Reviews, 22 (4), 502-548.

Paxinos, G, \& Watson, C. (1997). The rat brain in stereotaxic coordinates (San Diego, CA/Academic Press).

Rabasa, C., Muñoz-Abellán, C., Daviu, N., Nadal, R. \& Armario, A. (2011). Repeated exposure to immobilization or two different shock intensities reveals differential adaptation of the hypothalamic-pituitary-adrenal axis. Physiology \& Behavior, 103 (2), 125-133.

Radley, J. J., Williams, B. \& Sawchenko, P. E. (2008). Noradrenergic innervation of the dorsal medial prefrontal cor- tex modulates hypothalamus-pituitary-adrenal responses to acute emotional stress. Journal of Neuroscience, 28 (22), 5806-5816.

Robbins, T. W. \& Roberts, A. C. (2007). Differential regulation of fronto-executive function by the monoaminutesuteses and acetylcholine. Cerebral Cortex, Suppl 1, 1151-1160.

Sandi, C \& Pinelo-Nava, M. T. (2007). Stress and memory: behavioral effects and neurobiological mechanisms, Neural Plasticity, 2007 Doi: 10.1155/2007/78970, 1-20.

Shanks, N., Griffithst, J. \& Anisman, H. (1994). Norepinephrine and serotonin alterations following chronic stressor exposure: mouse strain differences. Pharmacology Biochemistry and Behavior, 49 (1), 57-65.

Shin, L. M. \& Liberzon, I. (2010). The neurocircuitry of fear, stress, and anxiety disorders. Neuropsychopharmacology, 35 (1), 169-191.

Shinba, T., Ozawa, N., Yoshii, M. \& Yamamoto, K. (2010). Delayed increase of brain noradrenaline after acute shock stress in rats. Neurochemical Research, 35 (3), 412-417.

Smith, D. G., Davis, R. J., Gehlert, D. R. \& Nomikos, G. G. (2006.). Exposure to predator odor stress increases efflux of frontal cortex acetylcholine and monoaminutesuteses in mice: Comparison with immobilization stress and reversal by chlordiazepoxide. Brain Research, 1114, 24-30.

Sudha, S. \& Pradhan, N. (1995). Stress-Induced changes in regional monoaminutesutese metabolism and behavior in rats. Physiology \& Behavior, 57 (6), 1061-1066.

Swiergiel, A. H., Leskov, I. L. \& Dunn, A. J. (2008) Effects of chronic and acute stressors and CRF on depression-like behavior in mice. Behavioral Brain Research, 186 (1), 32-40.

Szafarczyk, A., Ixart, G., Gaillet, S., Siaud, P., Barbanel, G., Malaval, F. \& Assenmacher, I. (1993). Stress. Neurophysiologic studies. Encephale, 19 (1), 137-142.

Viana, M. B., Tomas, C. \& Graeff, F. G. (1994). The elevated T-maze: a new animal model of anxiety and memory. Pharmacology Biochemistry and Behavior, 49 (3), 549-554. 